\title{
Az irónia lényegi jegyének keresése az elméleti pragmatikában
}

1. Bevezetés. Vajon rátapint-e az irónia lényegére az ÉKsz. ${ }^{1}$ - és változatlan formában az ÉKsz. ${ }^{2}$ - ezzel a rövid meghatározással: „rejtett, szellemes, finom gúny"? Vagy pontosabb az az antikvitásból örökölt, sokat idézett definíció, amely szerint az irónia eszközével (akár trópus, akár gondolatalakzat) az ellenkezőjét értjük az alatt, amit mondunk? Esetleg mindkét felfogás túláltalánosító vagy részleges, és valami másban keresendő az irónia sine qua nonja? A fogalomértelmezési polémiák az ún. elméleti pragmatika iróniával foglalkozó szakirodalmát is megtöltik GRICE $(1975,1978)$ klasszikus tanulmányai óta. Bár a lexikográfus és a pragmatikakutató céljai különböznek, az irónia nem tartozik a hétköznapi ember számára obskúrusnak hangzó nyelvészeti terminus technicusok közé (szemben, mondjuk, a szinekdochéval vagy a litotésszel), ezért aligha lenne vonzó az elsődlegesen a hétköznapi nyelvhasználatra fókuszáló pragmatikában messzire eltávolodni az irónia laikus fogalmától. Persze korántsem biztos, hogy ez a laikus fogalom egynemü, egységes és könnyen megragadható. Meg kell azonban kísérelnünk hozzáférni, mielőtt az egyik vagy másik elméletnek kedvezően kiválogatott, sőt nemritkán kitalált példák, részrehajló gondolatkísérletek tévutakra vinnének.

Az alábbiakban először bemutatom a pragmatika főbb iróniaértelmezéseit a jelen terjedelmi keretekhez igazodva. Ezt követően összefoglalom, hogy 100 egyetemi hallgató válaszai alapján milyen következtetéseket vonhatunk le az irónia hétköznapi fogalmáról és feltételezett funkcióiról. A tanulságok fényében tisztázom saját álláspontomat, kitérve az irónia és az ugratás, valamint az irónia és a szarkazmus viszonyára. Végül magyarázatot keresek arra, miért társul az irónia zavartalanul más trópusokkal, gondolatalakzatokkal, és miért érezzük olyan gyakran humorosnak. A nyelvi példaanyag részint zenei anekdotákból, részint a hivatkozott szakirodalomban sürün idézett ironikus (vagy legalábbis annak mondott) megnyilatkozásokból tevődik össze.

2. Iróniaértelmezések a pragmatikában. Az irónia megszokott velejárója a nyelvhasználatnak. Vannak ugyan müfaji-szövegtípusbeli, társadalmi és kulturális korlátai, mégis annyira jellemző társalgási „füszer” és „fegyver”, hogy a pragmatikának szinte kezdettől fogva volt mondanivalója róla. Fölvethető a kérdés, hogy ez a mondanivaló mennyiben tükrözi az iróniakutatásban érdekelt többi tudományterület eredményeinek ismeretét, ám fontosabb talán annak a megértése, hogyan merül fel az irónia problémaként a pragmatika számára, és milyen irányokba vitte el az irónia lényegére vonatkozó elméletalkotást, szembesülve az empirikus és teoretikus kihívásokkal. Menjünk tehát vissza a kezdetekhez!

2.1. GRICE $(1975,1978)$. Az iróniának több fajtáját különböztetjük meg. GRICE és általában a pragmatika a beszélő által szándékolt verbális iróniát állítja középpontba, de találnunk kell valamit, ami a képi, zenei vagy multimodális iróniára, a szituációs iróniára, a drámai iróniára, a romantikus iróniára stb. is igaz, 
különben széthullik vagy (jobb esetben) metaforizálódik az iróniafogalmunk. GRICE (1975: 53, 1989/2011: 37-38) először lényegében megerősíti a klasszikus retorikának tulajdonított ,az ellenkezőjét érteni azon, amit mondunk”' meghatározást, amikor a minős é g kategóriája alá rendelt első társalgási ma x i m a („Ne mondj olyat, amit hamisnak hiszel!”) kihasználására visszavezethető i mpli k a ú rá val magyarázza az iróniát (ahogy a metaforát, a túlzást és a meiózist/alullicitálást is). A konvencionális jelentésből (conventional meaning) indul ki, amely változhat, nem pedig a kevésbé dinamikus s zó s ze rinti jelentésböl (literal meaning) - amire kritikusai ritkán figyelnek föl -, s így nem zárja ki, hogy egy implikátum idővel konvencionalizálódjon (1975: 58, 1989/2011: 42; vö. NEMESI 2006, 2009: 64-65). A konvencionalizálódott ironikus kifejezések (pl. Szép kis [...], mondhatom) ezek szerint elveszíthetik implikatúrajellegüket, miközben továbbra is ironikusnak érezzük őket. Ennél is zavaróbb, hogy rengeteg ironikus megnyilatkozás nem az ellenkezőjét sugallja annak, amit szó szerint vagy konvencionálisan jelent, hanem valami mást. Ilyen az (1)-ben dőlt betủvel kiemelt is:

(1) Pablo Sarasate spanyol zeneszerzőt és hegedűvirtuózt egy hölgy vacsorára hívta ,a hegedüjével együtt”.

- Kedves hölgyem - válaszolta neki -, én boldogan elmegyek, de a hegedüm nem szokott vacsorázni. (KzAk. 225; Ma. 418.)

Ha elfogadná ironikusnak, GRICE (1978: 123-125, 1989/2011: 53-55) három lényeges dolgot állítana az (1)-ről. Az egyik, hogy benne van, ami minden ironikus megnyilatkozás kulcseleme: egy negatív jelzőkkel (elítélő, ellenséges, felháborodott, lenéző, megvető stb.) leírható érzés, attitüd, értékelés (Sarasate viszonyulása ahhoz, hogy a hegedüjét is vinnie kellene a vacsorára, vagyis elvárják, hogy játszszon a hangszeren, ezért hívják meg). A másik: nem kell ahhoz ironikus hanglejtés, hogy a válasz iróniáját megértsük, sőt nem is biztos, hogy van az iróniának önálló, csak rá jellemző hanglejtése (ez GRICE szerint kísérletileg ellenőrizhető), noha szóban kétségkívül az iróniával kifejezett érzésnek, attitüdnek megfelelő hanglejtést kell választani. Végül a harmadik: Sarasate megnyilatkozása színlelt: csupán tetteti annak a megjegyzésnek a komolyságát, hogy a hegedüje nem szokott vacsorázni, hiszen nyilvánvaló, hogy a hegedủ nem ember, sőt nem is élőlény.

Nem világos azonban, miképp egyeztethető össze mindez az irónia korábban vázolt implikatúramodelljével, amelyet GRICE nem revideál. A negatív értékelés az irónia (egyik) implikátuma? Mindig sérül a minőség első maximája, amikor ironizálunk? Mi a szerepe a hanglejtésnek az irónia megértésében? Vannak-e más jelölői az iróniának? GRICE kritikusai közül némelyek nemcsak azt kérdőjelezik meg, hogy az ironikus beszélő szándéka szükségszerüen a fordítottja a szó szerinti (vagy konvencionális) jelentéssel kifejezettnek, hanem azt is, hogy az iróniának föltétlenül negatív értékelést kell tartalmaznia (1. alább). KAUFER (1981:

${ }^{1}$ Jóval árnyaltabb képet fest az iróniáról CICERO (A szónokról, 2.67.269-273; 1. CICERO /2012: 347-349) és az a QUINTILIANUS is, akitől a fönti meghatározás valóban idézhető (Szónoklattan, 8.6.54-56, 9.2.44-53; 1. QUINTILIANUS /2008: 558, 582-584; vö. KOMLÓSi 2007-2008: 96-101). 
499-501) rámutat arra, hogy bármelyik társalgási maxima megsértése iróniához vezethet, nem kizárólag a minőségé, amit HOLDCROFT (1983: 507) azzal egészít ki, hogy az irónia nem is föltétlenül sért maximát (ez viszont - ha nem a minőség, akkor a mennyiség és a mód megfelelő maximáira tekintettel - erôsen kétséges).

2.2. ClaRK és GERRIG (1984). A görögből származó szó feltételezett eredeti jelentésével ('színlelés', 'tettetés') és GRICE (1978) harmadik kiegészítésével teljes összhangban a CLARK-GERRIG szerzőpáros gondolatmenetéből az következik, hogy Sarasate az (1)-ben úgy tesz, mintha tudatlan lenne, és komolyan gondolná, hogy címzettje nincs tisztában azzal, hogy a hegedűk nem szoktak vacsorázni - de mivel ez abszurd gondolat, a hölgy azonnal meg fogja érteni, hogy a müvész színlel, így fejezve ki véleményét az effajta meghívásról, egyúttal vissza is utasítva azt. Az elmélet szerint tehát egy $B$ beszélőnek van egy elsődleges $K$, valamint egy elképzelt vagy valóságos, jelen lévő vagy jelen nem lévő, „be nem avatott" $K$ ' közönsége, akihez/amelyhez nem mint $B$, hanem mint egy naiv, tájékozatlan vagy tévedésben leledző $B$ ' beszél. A $K$ közönség számára fölfedezhető, hogy $B$ színlel: $B$ '-ként szól $K^{\prime}$-höz, a célja pedig ezzel az, hogy fölismertesse $B$ ', $K$ 'és a $B^{\prime}$-ként mondottak iránti attitüdjét (CLARK-GERRIG 1984: 122). Az ironikus hanglejtés magyarázata éppen a tettetés; az, hogy $B$ nem a saját, hanem $B$ ' „hangján” szólal meg. Az irónia áldozata CLARK és GERRIG szerint $B$ ' (a tudatlan beszélö) és/vagy $K^{\prime}$ (a tudatlan közönség). Az (1)-ben azonban $K$, azaz maga a hölgy az áldozat, aki vacsorájának pompáját Sarasate (föltehetően ingyenes) hegedűjátékával kívánta volna emelni.

CLARK és GERRIG nem jelenti ki kategorikusan, hogy az ironikus tettetésben negatív viszonyulás fejeződik ki. Csupán ,aszimmetriáról” beszélnek: „valószínübb" valamilyen pozitív gondolat tettetése negatív attitüddel, mint fordítva, mert a társalgásban általában a pozitív gondolat (hogy jól vagyunk, minden rendben van, minden kitűnő, sikerült valami stb.) az elvárás, a „norma”, amely viszont nem mindig teljesül (vö. SPERBER-WILSON 1981: 312). Ha megvan a „közös alap” a felek között, a közönség rá fog jönni, miért releváns az ironikus megnyilatkozás. Ennek a közös alapnak a mibenlétét persze ki kell fejteni (l. CLARK-CARLSON 1981). Utóbb CLARK (1996) kö zö s te t te té s nek (joint pretense) tekinti az iróniát, amelynek két rétege van: $1 . B$ tetteti, amit $K$-nak mond; 2. $B$ ' komolyan mond valamit $K^{\prime}$-nek. De ha ugyanez igaz a túlzásra, az alullicitálásra és a költői kérdésre is (márpedig CLARK ezt állítja), mi lesz az irónia saját vonása? Marad a figyelem ráirányítása a naiv, tájékozatlan vagy téves vélekedésre és $B$ attitüdjére $B^{\prime}, K^{\prime}$ (vagy esetleg $K$, illetőleg a naiv, tájékozatlan, téves gondolat) iránt. Amenynyiben ezt egy túlzó, alullicitáló vagy költői kérdésként megfogalmazott megnyilatkozásról szintén el lehet mondani, akkor az ironikus is egyben.

A színészt és a parodistát ismerjük úgy, mint aki belebújik egy $B$ ' szerepbe, hogy $K$-hoz és egy $K^{\prime}$-höz is tudjon beszélni. Bár a néző néha összekeveri a fikciót a valósággal, amire a fikció akár rá is játszhat (1. a valóságos virtualitás fogalmát: CASTELLS 1996/2005: 489-493), a színpad, a filmvászon, a jelmez, a hanghordozás, a jelenetekre tagolás, a vágás és számos más szemiotikai „nyom” biztosítja, hogy $K$ végig úgy tekintsen $B$-re, mint $B$ '-re. Az irónia általában egy-egy megnyilatkozásra korlátozódó, alkalmi „szerepjáték”. Szemiotikai nyomok nélkül nem 
ismernénk föl a tettetést, ezért CLARKnak és GERRIGnek jobban rá kellene világítania ezekre a nyomokra (az ironikus hangtónus csupán egy közülük; vö. MUECKE 1978; ROCKWELL 2000; ATTARDO et al. 2003; KOMLÓSI 2014; GARMENDIA 2018: 107-125). Ez talán pótolható hiányosság, ám elméletük megdől, ha $B$ a saját „hangján” is képes iróniára. Az olvasó eldöntheti, indokolt-e egy $B$ ' (és egy $K^{\prime}$ ) bevezetése a (2)-höz:

(2) Egy zeneszerző dicsekszik Josephine Bakernek:

- Alig írok meg egy slágert, már az egész világon éneklik!

Mire Baker:

- Söt, a legtöbbet még elöbb. (Ma. 328.)

S ha nem indokolt, és az sem igaz, hogy Baker szándéka az ellenkezője lenne annak, amit mond, GRICE (1978) első kiegészítéséhez jutunk vissza: a negatív attitüd, értékelés implicit módon benne van a válaszban ('a zeneszerző slágerei nem mind eredeti szerzemények').

2.3. SPERBER és WILSON $(1981,1992,2012)$. Első pillantásra hasonlónak látszik CLARK és GERRIG elképzeléséhez a relevanciaelmélet iróniafelfogása, amely az e mlít é s (mention) és a has ználat (use) megkülönböztetéséből ered. Az iróniát SPERBER és WILSON (1981) az olyan említéses jelenségekkel állítja rokonságba, mint az egyenes vagy a függő idézés. Aki ironizál, nem azért idézi szó szerint vagy szabadon valaki másnak a megnyilatkozását, mert be akar számolni róla hallgatóságának, hanem úgy visszhangoztatja, hogy egyben kifejezze az ahhoz való viszonyulását is. Ezt a viszonyulást a későbbiekben dis s zociatív at t i t ủ d k é n t jellemzik: a beszélö eltávolítja magát attól a megnyilatkozástól, amelyet visszhangoz, nem azonosul vele (WILSON-SPERBER 1992, 2012). Az irónia megértését ugyanaz az általános megismerő mechanizmus biztosítja, mint minden más nyelvi megnyilatkozásét: a re le va n c i a k e r e sés, a „minél nagyobb kognitív hatást minél kisebb kognitív erőfeszítés árán" gazdaságossági elve (vö. SPERBER-WILSON 1986/1995: 118-171). A szerzők eleinte kissé szkeptikusak a benyomások és attitüdök „retorikai pragmatikájának” az „erősen kommunikált” jelentésekre összpontosító „logikai pragmatikába” való beolvaszthatóságát illetően, ám azután bevezetik a gyenge implikatúra (weak implicature) fogalmát az implicit közlésekkel járó bizonytalanságok, többé-kevésbé valószínü, nyitott, elmosódott jelentések számára. Nem vitás, hogy a megnyilatkozásokkal közvetített attitüdök és benyomások is kontextuális hatást eredményeznek.

Az említéses visszhangoztatás eszméjét hamar föl kellett cserélni az ér t e 1 mező has o nlósággal (interpretive resemblance, WILSON-SPERBER 1992: 64). Az alapeset az volt, amikor valaki szó szerint idéz valakit sugallt disszociatív attitüddel. Sok ironikus megszólalás tényleg ilyen. Máskor viszont nem szó szerint idéznek valakit, és úgy is ironikus tud lenni a megnyilatkozás. Lehet, hogy nem is idéznek konkrétan valakit, hanem egy embertípust, valamilyen bölcsességet, társadalmi normát, elvárást, amely éppen nem teljesül vagy nem adekvát. Sőt, nemritkán nincs is szó idézésröl, csupán valaki(k)nek valamilyen gondolatot tulajdonítanak egy ahhoz hasonló másik gondolattal reprezentálva azt (értelmező 
hasonlóság), és ettől határolja el magát a beszélő az iróniával (vö. a CLARKGERRIG-féle tettetéssel). A relevanciaelmélet képviselői az irónia attributív (valakinek tulajdonított) és metareprezentációs (mentális reprezentáció egy másik mentális reprezentációról) természetét hangsúlyozzák, nem adva fel a visszhangoztatás ötletét (vö. az allúzió retorikából ismert fogalmával). Így azonban oly mértékig kitágítják annak jelentését, hogy az már intuícióellenes. Sarasate az (1)ben vagy Baker a (2)-ben mit visszhangoztat? - kérdezhetjük. Sarasate talán azt a gondolatot tulajdonítja az ôt invitáló hölgynek, hogy vele együtt a hegedűjét is megvacsoráztatná? A hölgy biztosan nem gondolt ilyet. Baker pedig a zeneszerző gondolatát reprezentálná ironikus válaszával? Ha SPERBER és WILSON igennel felelne, akkor gyakorlatilag bármilyen megnyilatkozás reprezentálhat vagy visszhangozhat bármilyen gondolatot, ami az elmélet kiüresedéséhez vezet.

Nézzünk egy példát, amely mind a tettetéses, mind a visszhangoztatásos koncepciónak megfelel:

(3) Az egyik esten, amelyet Liszt Ferenc a szentpétervári udvarban adott - ahol mindig nagyon jól fogadták -, Miklós cár, aki nem volt nagy zenebarát, szóba elegyedett egy hölggyel, és, nem törődve Liszt játékával, igen hangosan beszélt. Liszt hirtelen abbahagyta a zongorázást, és otthagyta a hangszert.

- Miért fejezte be a játékot?

- Amikor az uralkodó beszél, mindenki másnak hallgatni kell - hangzott az elmés válasz. (KzAk. 141; Ma. 113.)

Akár úgy értelmezzük, hogy Liszt egy $B$ ' hangján szólal meg, akár úgy, hogy egy általánosan elfogadott „,bölcsességet” visszhangoz, az implicit attitüd hordozza az iróniát: a cárnak a müvészettel és a mủvésszel szembeni tiszteletlen viselkedéséről fejezi ki Liszt - a felszínen udvariasan, épp ezért nagyon elmésen - a véleményét. A probléma az, hogy a két teória empirikus tesztelése nem jól dokumentált, sokféle forrásból összeállított iróniakorpuszok felhasználásával történik, hanem javarészt kitalált, szelektált adatokkal, manipulált kontextusokkal. Az olyan kísérletek, amelyekben az ironikus kulcsmegnyilatkozások kontextusát variálják, csak annyit bizonyítanak, hogy a visszhangoztatás megkönnyíti az irónia megértését; azt nem, hogy minden ironikus megnyilatkozás visszhangszerü (1. pl. JORGENSEN et al. 1984; KREUZ-GLUCKSBERG 1989; KEENAN-QUiGLEY 1999). A visszhangoztatást - GARMENDIÁval (2018) egyetértve - inkább az iróniára rávezető egyik potenciális nyomnak kell tekintenünk (az ironikus hanghordozás, mimika stb. mellett).

2.4. AMANTE (1981); HAVERKATE (1990). A grice-i minőség kategóriája alá rendelt maximák megfogalmazása bírálható amiatt, hogy a kijelentésekre korlátozza az őszinteség, igazságteliség társalgási posztulátumát. A b e s zédakt u s-e lméle t a különféle verbális cselekvésfajtákhoz (illokúciós aktusokhoz) igazítja az ős zinteség i feltételt a többi sikerességi feltétellel (előkészületi feltétel, propozíciós tartalmi feltétel, lényegi feltétel; 1. SEARLE 1969/2009) együtt. Így például egy (költői) kérdés is lehet ironikusan öszintétlen, mint a következő Massenet-anekdotában láthatjuk (vö. BROWN 1980: 114): 
(4) A Manon egyik előadása után, amelyen a tenor végig fél hanggal lejjebb énekelt, Jules Massenet a színfalak mögött találkozott az énekessel, aki boldog várakozással lépett oda a szerzőhöz:

- Kedves mester, remélem, meg volt elégedve?

- Ó, hogyne! Ó, hogyne! - válaszolta Massenet. - De mondja, hogy tudott énekelni ezzel a szörnyü zenekarral, amely egész este fél hanggal magasabban játszott? (KzAk. 216-217; Ma. 121.)

Míg a tenor kérdése őszinte, és megfelel a kérdés szokásos sikerességi feltételeinek (SEARLE 1969/2009: 80), Massenet-é nem az, hiszen nem gondolja, hogy a zenekar játszott fél hanggal magasabban. A tenor produkcióját tartja szörnyünek, aki észre sem vette, hogy végig fél hanggal alacsonyabban énekelt. Nem pusztán az őszinteségi feltételt (Massenet szeretne szert tenni információra) érinti az irónia: mint közvetett beszédaktus a megnyilatkozás elsődlegesen nem is kérdésnek lett szánva, hanem szemrehányásnak (lényegi feltétel); a propozíciós tartalom és az előkészületi feltételek is ennek megfelelően értékelődnek át.

Félretéve AUSTIN (1962/1990) és SEARLE (1969/2009) „parazita” beszédaktusokkal szembeni fenntartásait, AMANTE (1981) az iróniával járó „perlokúciószerü" affektív hatást emeli ki. (Szerinte az illokúciós és a perlokúciós tartalmak egymásba fonódnak, ezért a „-szerü”.) K ö zve te t t b e s zé daktusnak tartja az iróniát több jelentésréteggel, s ennek megfelelően a „szabályai”, amelyeknek a leírására vállalkozik, összetettebbek. Három résztvevője van: az eirón (aki ironizál), a közöns ég e és az irónia célpontja, bár az utóbbi kettő, sőt önirónia esetén mindhárom egybeeshet. Egy $P$ és $P$ ' propozíció összeütközéséről beszél - de tisztában van vele, hogy az ironikus összeütközés, oppozíció, ellentét, tagadás sokféle dolgot jelenthet (vö. KoMLósI 2012). Az eirón kell, hogy adjon valamilyen nyomot (vagy nyomokat), amely rávezeti a közönséget az iróniára. AMANTE szerint már a SEARLE-féle normál bemeneti és kimeneti feltételeket is módosítani kell az irónia kedvéért, nem csupán a sikerességi feltételeket. Számolni kell azonban a valószerü, az őszinteségi feltételt - látszólag legalábbis - nem sértő iróniapéldákkal (pl. valakiről, aki nagyon udvariatlan volt: „Szeretem azokat az embereket, akik tudnak viselkedni”; 1. HAVERKATE 1990: 92), és jó lenne közelebbről meghatározni azt a bizonyos affektív hatást, amely az irónia sajátja. HAVERKATE (1990) is az irónia által keltett perlokúciós hatást helyezi előtérbe, amelynek a fő eleme nála a várakozások megsértése és a személyközi távolság. Tegyük hozzá: az egymás között más(ok)on ironizálók oldottabb hangulatot teremthetnek, és bizalmasabb kapcsolatba kerülhetnek egymással. A szerző úgy véli, egy negatív explicit értékelés pozitív sugallatú ironikus megfordítása azért „,szokatlan”, mert egyszerre két társalgási maxima, a minőségi és az udvariassági ellen vét (HAVERKATE 1990: 93). Ám, ha azt mondjuk, szokatlan, az előfordulását nem zárjuk ki.

2.5. LEECH (1983, 2014). Az udvariasságnak LEECHnél számos maximája van, amelyek a grice-i együttmüködési alapelvet (Cooperative Principle, CP) kiegészítő udvariassági a lapelv (Politeness Principle, PP) hatálya alá tartoznak a „személyközi retorikán” belül. Az iróniát mint látszatud- 
variasságot az ugratással mint látszatudvariatlansággal állítja szembe: mindkettő olyan másodrendủ társalgási elv, amelyet a CP-re és a PP-re hivatkozva lehet meghatározni. Az i rón i a elv (Irony Principle, IP) azt mondja ki, hogy „Ha sértést kell okoznod, azt legalább úgy tedd, hogy ne kerülj nyílt konfliktusba a $\mathrm{PP}-\mathrm{vel}$, de indirekt módon, implikatúra által megérthesse a hallgató megjegyzésed sértő tartalmát" (LEECH 1983: 82). ${ }^{2} \mathrm{Az}$ i r ó n i a tehát sértő, de indirektségbe (implikatúrába) burkolózik, ami megvédi a beszélőt attól, hogy összetűzés alakuljon ki közte és az irónia áldozata között. Az u g ra tá s ezzel szemben explicit udvariatlanság fordított szándékkal: szolidaritást implikál („nem kell komolyan venni, hiszen nyilvánvalóan nem igaz”, „olyan közvetlen a viszonyunk, hogy ezt is megengedhetjük magunknak egymással szemben").

Jegyezzük azért meg, hogy az emberek általában nem szeretik, ha ugratják öket, viszont sok olyan ember van, aki szeret másokat ugratni. Ez arra utal, hogy nemcsak az iróniának van ,áldozata”, hanem az ugratásnak is lehet: az ugratás explicit udvariatlanságát nem tünteti el teljesen az implicit barátságosság, s bár frappánsnak hangzik az irónia negatív és az ugratás pozitív sugallt attitüdjének - a látszatudvariasságnak és a látszatudvariatlanságnak - a kontrasztja, a valóságban nincs éles határ az irónia és az ugratás között, mint ahogy az irónia és a szarkazmus között sincs. Az is kérdéses, hogy a nyílt sértés vajon mindenkor fenyegetőbb-e, mint az ironikus sértés, amely intellektuális fölényt kölcsönözhet az ironizálónak, és nevetség tárgyává teheti az irónia áldozatát. LEECH (2014: 236) mindenesetre úgy összegzi az irónia funkcióját, hogy az a támadás és a védekezés szempontjából is a beszélő érdekét szolgálja: elérhetővé teszi az udvariatlan célt az áldozat kárára, ugyanakkor az ,ártatlanság” álarcát ölti - mint minden társalgási implikatúra, szükség esetén törölhetö, de ha nem is „tagadja le” a beszélő, hogy kritizált vele, aligha válaszolnak rá nyílt udvariatlansággal, legföljebb másik iróniával. A dicsérő vagy pozitív irónia létezését - amit ATTARDO (2000: 796) FONTANIER (/1968) retorikája nyomán az a s z te i z m u s (a magyar stilisztikai-retorikai szakirodalomban: enyelgés) alakzatával próbál bizonyítani - LEECH iróniaértelmezése kizárja, az ugratás fönti meghatározásába viszont jól beleillenek. Kevésbé világos az olyan példák státusa, mint a „Bocs, hogy megint ilyesmivel zavarlak, de újabb magas osztalékot könyvelhetsz el a részvényeid után..." - értesít telefonon a bróker (BROWN 1980: 114; idézi ATTARDO 2000: 976). Irónia, ugratás vagy valami más(fajta humor)?

2.6. GiORA (1995, 2003); ATTARDO (2000). A grice-i implikatúramodell megreformálására vállalkozik GIORA (1995) és ATTARDO (2000) is, de más-más kiindulópontból. GIORA megértési modellje úgy kétlépcsős, hogy nem a szó szerinti jelentés automatikus aktiválódását föltételezi első lépcsőként, hanem a legmegszokottabb, leggyakoribb, leginkább konvencionális, prototipikus ve zérjelenté s e két (salient meanings, vö. GIORA 2003; nota bene: GRICE sem a szó szerinti jelentésre épít, míg SEARLE például igen; 1. SEARLE 1979). Az irónia esetében is a vezérjelentés hívódik először elő (akár szó szerinti, akár nem), és egy másik jelentés, amely indirekt módon tagadja, de nem fölváltja az elsőt, a kettő

${ }^{2}$,If you must cause offence, at least do so in a way which doesn't overtly conflict with the PP, but allows the hearer to arrive at the offensive point of your remark indirectly, by way of implicature." 
közötti negációs viszony hordozza az iróniát. ATTARDO teljes egészében pragmatikai (következtetéses) folyamatként írja le az iróniamegértést, mivel nincs olyan egyszerü szemantikai sémája, mint a jelentésmegfordítás. A grice-i CP szerinte sérül, de a $1 \mathrm{egkisebb} \mathrm{megakas} z$ tá s e lve (principle of least disruption) garantálja, hogy ez a lehető legkisebb társalgási egységre korlátozódjon, és a társalgók jelentést tulajdonítsanak neki. Az ironikus megnyilatkozás az adott kontextusban „nem helyénvaló”, noha releváns, és nem feltétlenül sérti meg a minőség első maximáját (mint már tudjuk, ATTARDO szerint nem is föltétlenül negatív értékelés). Ez a h e ly é n va ló s á g (appropriateness) egy „ötödik maxima” (valójában kategória; 1. a kanti kategóriák és a hozzájuk besorolt maximák státusát), amelyet az ironizáló kihasznál a CP-t (állítólag) megsértve, de a „perlokúciós együttmúködési alapelv” (PCP) jegyében, azaz valamilyen perlokúciós célért (vö. beszédaktus-elmélet). A ,kontextuális helyénvalóság” azon áll vagy bukik, hogy a megnyilatkozás összes előfeltevése azonos vagy összeegyeztethetö-e a kontextus előfeltevéseivel.

Az lehet a benyomásunk, hogy mindkét javaslatban épp az sikkad el, mi is az irónia lényege. GIORÁnál van egy explicit és egy implicit jelentés (utóbbit nyilván az előbbi és a kontextus alapján vezetjük le), és a köztük lévő különbség (tagadó viszony) fölismeréséből származik az irónia, amely azért jó, mert a direkt tagadás túl arculatfenyegető vagy unalmas lenne. De hogyan alkalmazhatnánk mindezt az itteni (1)- és (2)-beli példánkra? Eleve kidolgozatlan, miként vezetjük le az implicit jelentést, és ha nem az implicit jelentés maga az ironikus jelentés, akkor mi az ironikus tartalom kognitív státusa? ATTARDO elfogadja, hogy ez valamiféle attitüd, de úgy véli, annyira széles skálán mozog, hogy nem lehet közelebbről meghatározni. Ehelyett olyan elméleti spekulációkba bocsátkozik, amelyek egész sor kérdést vetnek fel, például: Mi is tulajdonképpen a „helyénvalóság” maximája? Beleillik-e a rendszerbe? Mi a viszonya a többi maximához? Nincs azokkal átfedésben? Helyesen értelmezi-e ATTARDO a CP-t, a relevanciamaximát és a maximakihasználást? Van-e értelme a CP „megkettőzésének” (PCP)? Mi a kapcsolat a CP és a PCP között?

2.7. DYNEL (2013, 2017, 2018); GARMENDIA (2010, 2015, 2018). A GRICE eredeti implikatúramodelljével leginkább rokonszenvező neo-grice-iánusok, DYNEL és GARMENDIA egyetértenek abban, hogy az ironikus attitüd mindig kritiku s (1. GRICE 1978), és hogy GrICE (1975: 49, 1989/2011: 34) nem véletlenül „csempészi bele” a társalgási implikatúra meghatározásába azt a félmondatot, hogy a beszélő vagy azt mondja, hogy $p$, ,vagy úgy tesz, mintha azt mondaná", hogy $p$, miközben azt implikálja, hogy $q$. Ha ugyanis a megnyilatkozás teljes jelentése a mondott (what is said) és az implikált (what is implicated) jelentés összege lenne, akkor az irónia azon alappéldái, amelyekben az implikált jelentés a mondott jelentés fordítottja, kontradikciót eredményeznének. A megoldás tehát, hogy a beszélő - technikai értelemben - ,nem mondja”, hogy $p$, hanem csak ,úgy tesz, mintha mondaná”. Ez a tettetéses felfogásokkal mutat rokonságot (1. ismét az irónia szó etimológiáját). Ugyanakkor nem technikai értelemben a beszélő mégiscsak mondja, hogy $p$, és $p$ jelentését felhasználva kalkulálja ki a $q$ implikált jelentést - azaz olyan, elméleten belüli problémáról van szó, amely csak annyit árul el az irónia lényegéről, hogy az ironikus megnyilatkozásjelentésnek 
nem (vagy nem föltétlenül) része a megnyilatkozás konvencionális jelentése, azt a beszélő nem (föltétlenül) tulajdonítja magának, nem kötelezi el magát mellette.

Egy ironikus megnyilatkozás implikatúrái többrétegüek. A konvencionális jelentésnek ütköznie kell valamivel, amit a beszélő gondol, de nem mond ki (viszont kikövetkeztethetővé tesz), és ebből az ütközésből válik nyilvánvalóvá a kritikus attitüd. Másfajta (pl. humoros) attitüdök is kapcsolódhatnak az ironikus megnyilatkozás jelentésrétegeihez, de mindenképp kell lennie benne negatív viszonyulásnak, kritikának valamivel/valakivel szemben. Ha a konvencionális jelentés kritikus, és a beszélő az implikatúrával dicsér, akkor az vagy nem irónia (1. ugratás, nem ironikus humor), vagy volt a megnyilatkozásnak egy olyan előzménye, amely érthetővé teszi, mi a kritika mégis benne (pl. valaki előzőleg álszerénykedett, majd ő bizonyult a legjobbnak, és erre reagál a beszélő a „pozitív iróniával”: „De ügyetlen vagy!”). DYNEL $(2013,2017)$ védi a minőség első maximájára épített grice-i magyarázatot. A valószerü (konvencionális jelentésükben is igaz) iróniapéldáknál a relevanciamaxima kihasználását tételezi föl, amiből egy olyan, „köztes” implikatúra származik, amely hamis (1. minőségmaxima), és ez lesz az alapja az iróniának (egy további implikatúrának): 1. „Szeretem azokat az embereket, akik tudnak viselkedni" $\rightarrow$ 'Szeretem, hogy tudsz viselkedni' (első implikatúra) $\rightarrow$ „Nem szeretem, hogy nem tudsz viselkedni' (második implikatúra). A nem kijelentés formájú, őszinteségi feltételt sértő ironikus beszédaktusokra (őszintétlen kérdések, felszólítások, gratulációk, köszönetnyilvánítások stb.) pedig egyszerủen kiterjeszti a minőség első maximáját. GARMENDIA (2018: 35-36) más útra tér: maximakihasználás helyett a „szó szerinti jelentés” (!) és a beszélőt motiváló meggyőződés (értsd: amit a megnyilatkozással elsődlegesen közölni akar) eltérését szeretné kimutatni, a beszédaktus-elmélet felé orientálódva.

2.8. TÁTRAI (2011, 2017); KOMLÓSI $(2012,2013,2015)$. A magyar pragmatikakutatók közül TÁTRAI $(2011,2017)$ funkcionális-kognitív elméleti keretet dolgozott ki, ebbe illeszti be az iróniát is. Mint fogalmaz, a verbális irónia „egy nyelvileg kifejtett és így valamilyen kiindulópontból megkonstruált reprezentáció felülírása egy olyan - inkább implicit, mint explicitté tett - kiindulópontból, amely megkérdőjelezi, de legalábbis relativizálja az adott reprezentációhoz kapcsolódó kiindulópont értelmezés- és értékelésbeli megfelelőségét a résztvevők által feldolgozott kontextuális körülmények között" (TÁTRAI 2011: 203, 211; 2017: 1053, 1068). Ez a nagyon körültekintő meghatározás igyekszik kikerülni minden olyan csapdát, amelyet a klasszikus (grice- és searle-iánus) pragmatika magában rejt. A r e prezen tá c i ó fogalmával elejét veszi a jelentés- és beszédaktusfajták körüli vitának. Az ,inkább” és a „legalábbis” partikulák óvatosan megengedők az explicitség-implicitség és az attitüd dimenzióján. Nem zárja ki (egyértelmüen) az aszteizmust (enyelgést), „pozitív iróniát”, ugratást, bár a szerző hozzáteszi, hogy az irónia alkalmazója „,kritikai attitüdjét érvényesíti”, és ,az általa ajánlott értékelési centrum adekvátabb voltát implikálja" (TÁTRAI 2017: 1054). Kétféle k i i n d u ló p o n tr ó 1 beszél, ahonnan ugyanazt a dolgot értelmezni-értékelni lehet, és a perspektivizá ci ó kognitív képességével magyarázza, hogy akár egyazon megnyilatkozás is képes két eltérő kiindulópontot (nézőpontot), illetőleg n é z ő pontváltást közvetíteni. Az irónia ennek megfelelöen reflexív vis zo- 
n y u lá s egy nézőponthozés azt tükrözőreprezentációhoz, legyen az másvalaki(k)é, magáé a beszélőé (1. önirónia), vagy esetleg általánosan kivetített, fiktív.

A klasszikus pragmatikából, a relevanciaelméletből és TÁTRAI funkcionáliskognitív elméletéből is merít KOMLÓsI, aki szerint az ironikus megnyilatkozás 1. metapragmatikai éberségre ösztönzi a hallgatót: ráirányítja figyelmét a mondott jelentés és legalább egy (vagy több) sugallt jelentés közötti eltérésre, fenntartva a pragmatikai jelentés többértelmüségét; 2. a megnyilatkozásra nézve k a t e g ó ria vál tá s, a beszélő és a hallgató nézőpontjából pers pektí vaváltás és perspektíva e melés; 3 . a beszélö szándéka éppen az, hogy metapragmatikai éberségre, illetőleg perspektívaváltásra és perspektívaemelésre ösztönözze a hallgatót (KOMLÓSI 2015: 163). A perspektívaemelés egy külső, „magasabb” nézőpont felajánlását jelenti, amelyből két „belső” nézőpont eltérése szemlélhető - gondoljunk Jane Austen Büszkeség és balítélet címü, iróniában gazdag és a mai napig méltán közkedvelt regényének első két szövegmondatára a vagyonos legényemberek mielőbbi megházasításának szükségességéről. Ám akár külső nézőpontot vesz föl az értő olvasó, akár egyszerüen csak az elbeszélő által ,általánosan elismert igazság”-ként jellemzett nézőponttal helyezkedik szembe, kritikus, disszociatív attitüdöt tesz magáévá, illetőleg ilyen attitüdöt tulajdonít az elbeszélőnek. Az 1. kitételről azt mondhatjuk, hogy minden társalgási implikatúrára érvényes lehet, a 2.-ról, hogy nincs minden ironikus megnyilatkozásban kategóriaváltás (pl. ironikusan: „Ügyes vagy!” $\rightarrow$ 'Ügyetlen vagy'), lehet viszont az ugratásban is, a 3.-ról pedig, hogy a beszélö szándéka több ennél: implicit módon ki akarja fejezni valamivel/valakivel kapcsolatos (kritikus) attitüdjét.

3. Az irónia hétköznapi fogalma. Két módszer kínálkozik az irónia hétköznapi fogalmának föltérképezésére: vagy megkérdezzük magukat a nyelvhasználókat (1. a vicc szövegtípusáról: HÁMORI 2017), vagy építünk egy mindennapi, spontán szövegből álló, hatalmas korpuszt, amelyből kikeressük az iróniára vonatkozó metapragmatikai megjegyzéseket (amennyiben találunk elegendő számban ilyeneket), hogy azokból vonjunk le következtetéseket. Az első könnyebben kivitelezhető, és más alanyokkal bármikor megismételhető. 2018 májusában öszszesen 108, egyetemi alapképzésben vagy osztatlan tanárképzésben tanuló hallgatóval töltettem ki az alábbi rövid kérdőívet (a válaszoknak hagyott üres hely mindhárom pontnál kb. négy kézzel írott sornak felelt meg):

Kérem, egy névtelen empirikus kutatás résztvevőjeként válaszoljon az alábbi kérdésekre! Kora: Neme:

Szakja:

1. Az irónia, ironikus, ironizál stb. szavakat a mindennapi nyelvben is használjuk. Ön szerint mi az irónia? Hogyan határozná meg, hogyan írná körül ezt a fogalmat?

2. Idézzen fel vagy találjon ki két jó példát az iróniára! (Röviden adja meg a beszédhelyzetet is!)

I.

II. 
3. Ön szerint miért élnek az emberek az irónia eszközével? Milyen kommunikációs célokat tudna felsorolni, amelyek betöltésére az irónia alkalmas?

A 108 kitöltött kérdöívből végül 8-at nem vettem figyelembe (az egyik hallgató más életkori csoporthoz tartozott, a többi hét lap pedig hiányos vagy semmitmondó volt), így lett $\mathrm{N}=100$. A válaszadók mindannyian a Pázmány Péter Katolikus Egyetem Bölcsészet- és Társadalomtudományi Karának hallgatói voltak, 18-27 évesek (átlagéletkoruk: 21,06 év), különböző szakosok (az anglisztikától a történelemig), 18 férfi és 82 nő (ez az aránytalanság a Kar hallgatói összetételét tükrözi). Az 1. és 3. kérdésre született válaszok visszatérő elemeit számszerüsítettem; a 2. kérdésnek egyrészt tesztfunkciója volt (aki nem írt két elfogadható példát, azt kizártam a vizsgálatból), másrészt fokozni igyekeztem vele a kitöltők metapragmatikai tudatosságát. Mivel a fogalmi meghatározás a nyelvi formából, a jelentésből és a kommunikációs célokból is kiindulhat, a 3. kérdésre adott válaszok az 1.-nél leírtak kiegészítéseként is fölfoghatók.

Néhány szó szerinti idézet a résztvevőktől: „Az irónia egy tulajdonság, szituáció, beszédhelyzet kifordítása azáltal, hogy az ellenkezőjét állítjuk, mindezt kiegészítheti egy sajátos, gúnyos hanglejtés, stílus”; „Különös éllel a hangunkban állítunk olyasvalamit, ami ellentétes azzal, amit valójában gondolunk”; „Az irónia az, amikor mást mondunk, mint amit valóban közölni akarunk. Általában itt nagy szerepe van a hangsúlynak, melyböl következtethetünk arra, hogy a közlö mit szeretne valóban mondani”; „Amikor valamit úgy mondunk, hogy félig vagy egyáltalán nem gondoljuk komolyan. Valamilyen »álca« mögé rejtjük mondandónkat”; „Az irónia számomra dicsérő szavak mögé rejtett gúny”; „A humort gúnyosan kifejező csipkelődés, élcelődés”; „Az irónia szerintem - absztrahálva minden könyvi tudástól - egy képesség, ami egy dologban, helyzetben, szóban képes több réteget láttatni és érzékeltetni”.

A kódolás első szakaszában, még ragaszkodva a hallgatók szóhasználatához, összesen 23 válaszkategóriát vettem föl: az ellenkezőjét/ellentétét érteni azon, amit mondunk (50); sajátos hanglejtés, hangsúly (29); (leplezett) gúny (25); humor (19); nem komolyan mondani valamit (14); nem szó szerinti, átvitt értelem (10); mást mondani, mint amit gondolunk (9); szarkazmus(hoz hasonló) (9); vicc, paródia (9); negatív, lekicsinylő állítás (6); kifigurázás, nevetségessé tétel (5); álcázott gondolat (3); csipkelődés, szurkálódás, élcelődés (3); (leplezett) sértés (2); burkolt közlés (2); leplezett vélemény (2); kritika, nemtetszés (2), beszédhelyzet kiforgatása (1); célozgatás (1); hangsúlyozni valamit (1); nem kedvelni valakit (1), szellemesség (1); több jelentésréteget láttatni (1). A második szakaszban a hasonló válaszokat összevontam. Így alakultak ki az 1. ábrán szereplő kategóriák és értékek. 


\section{1. ábra}

A válaszadók iróniameghatározásainak fő elemei $(\mathrm{N}=100)$

Az ellenkezőjét érteni azon, amit mondunk

Negatív attitűd (kritika, gúny, sértés stb.)

Humor, viccelődés

Sajátos hangl ejtés, hangsúly

Nem szó szerint érteni azt, amit mondunk

Nem komolyan mondani valamit

Burkolt közlés

Kifigurázás, nevetségessé tétel

Egyéb

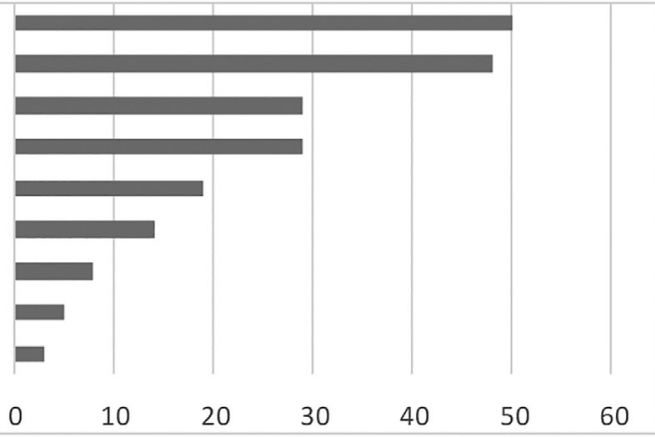

A „kifigurázás, nevetségessé tétel” azért maradt külön kategória, mert nem egyértelmü, hogy a „negatív attitűd”-höz vagy a „humor, viccelődés”-hez számítódjon-e. Ha mindkettőhöz hozzáadnánk, a különböző szavakkal leírt (és sokszor a leplezett, burkolt jelzőkkel kísért) negatív attitüd lenne a meghatározások leggyakoribb eleme. Mindenesetre a prototipikus (verbális) irónia a megkérdezettek szerint a mondottakkal ellenkező jelentést fejezi ki negatív attitüddel, amire sajátos hanglejtés hívja föl a figyelmet, és a negatív attitüd ellenére (vagy éppen amiatt) humoros szándék is van mögötte. Nem tudni, mekkora a szerepe a tanult, tankönyvi definíciónak abban, hogy minden második válaszadó „az ellenkezőjét érteni azon, amit mondunk" felfogást képviselte. A magyar szakosokat pontosan ezért eredetileg szerettem volna kizárni a kutatásból, de végül 6 leendő magyartanár bekerült a mintába (további két hallgató pedig nem adta meg, milyen tanári szakpárra jár). Az iskolai definícióval azonban bizonyára a többiek is találkoztak.

Ha a kommunikációs célokat nézzük, rendkívül színes kép rajzolódik ki a hallgatói válaszokból. Az első kódolás 25 kategóriát rögzített: humor(izálás), vicc(elődés), jókedv előidézése (58); felszültségoldás, -enyhítés (18); (rejtett) gúny, szarkazmus (13); burkolt vélemény kifejezése, célzás (13); ne legyen olyan sértó, bántó a negatív vélemény (12); színesíti, változatossá teszi a kommunikációt, kreatív (11); nyomatékosítás, kiemelés, felhívás (11); figyelemfelkeltés, figyelemirányítás, hatáskeltés (11); sért(eget)és, bántás, leszólás, lejáratás (10); kritika, negatív vélemény, elégedetlenség, nemtetszés kifejezése (10); konfliktuskerülés, védekezés (9); a komolyság megtörése, játékosság, kötetlenség (9); kapcsolaterősítés, szimpátiakeltés (barátok között) (8); vélemény, (érzelmi) viszonyulás kifejezése (8); saját tudásunk, intelligenciánk csillogtatása (5); kellemetlen, kínos helyzet megkönnyítése (4); kifigurázás, kiparodizálás (3); csipkelődés, szurkálódás, fricska (3); szórakozás, (ön)szórakoztatás (3); nem egyértelmű válasz adása (2); csoportképzés, közösségteremtés (2); nevetni saját nyomorunkon (1); információadás (1); érzelmek elfedése (1); elgondolkodtatni másokat (1). Ezeket tömörítik a 2. ábra kategóriái. ${ }^{3}$

${ }^{3}$ Vö. ROBERTS és KREUZ (1994) eredményeivel, akiknek az alanyai (amerikai egyetemisták) az iróniahasználat céljaként elsődlegesen a negatív érzelem kimutatását (94\%), a humort (65\%), a nyomatékosítást (35\%) és a tisztázást (35\%) jelölték meg (magyarul ismerteti: NEMESI 2009: 129-131). 


\section{2. ábra}

Az irónia kommunikációs céljai $(\mathrm{N}=100)$

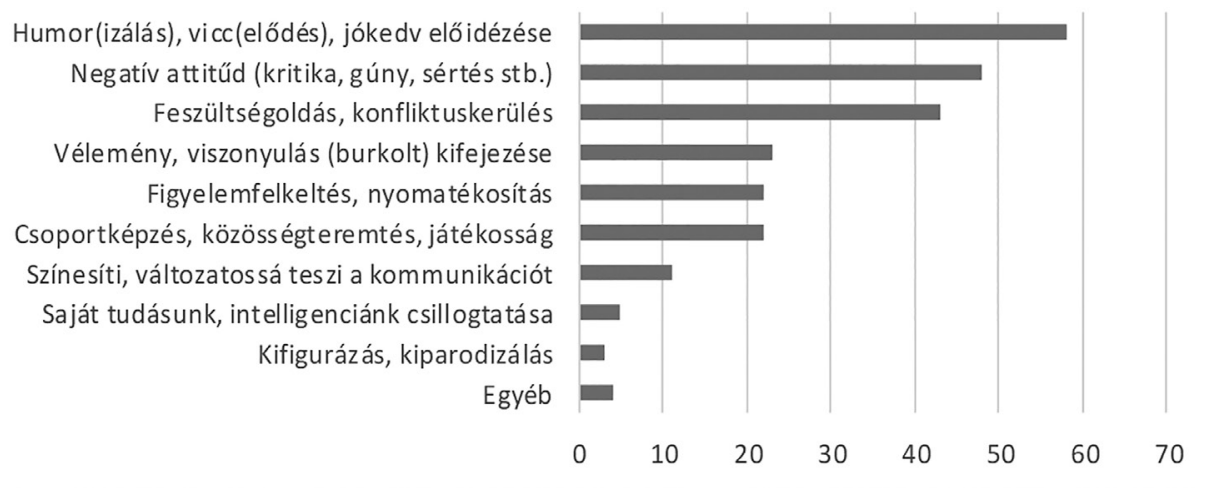

Bár, mint láthatjuk, a humor ezúttal megelőzi a negatív attitüd dimenzióját, ha együtt tekintjük a hallgatók válaszait, azaz a példáikat is szemügyre vesszük az 1. és a 3. kérdésre adott válaszaik mellett, mindössze 3 olyan megkérdezett akad, akinél a negatív attitüd egyáltalán nem bukkan fel; 97\%-uknál azonban valamilyen formában - hangsúlyosan vagy kevésbé hangsúlyosan - megjelenik.

4. Egy minimalista iróniaértelmezés. Az eddigiek alapján nagyon is érthető, miért nem pofonegyszerü a válasz arra a kérdésre, hogy mi tesz valamit ironikussá. A sokféle alakváltozat, rávezető nyom, összetett szándék és kommunikációs funkció elfedheti azt, ami a közös jegy. Amellett kívánok ugyanis érvelni, hogy létezik ilyen közös jegy, mégpedig a sugallt negatív (kritikus, gúnyos, disszociatív, megkérdöjelezö) attitüd, amely mindenféle - nyelvi, nem nyelvi és multimodális - irónia sajátja (vö. NEMESI 2009: 8, 99; illetve fentebb: 2.1., 2.3., 2.5., 2.7., 2.8.). Kétféle értékelés, viszonyulás vagy attitüd van szükségképpen jelen az iróniában: az egyik, amelyik sugallt, kétségbe vonja egy másik attitüd érvényességét, amelyik nyelvi megnyilatkozások esetében következhet az explicit jelentésből vagy egy ahhoz társuló implikatúrából is, tudniillik az irónia lehet többrétegü implicit értékelés - de mindig jelen van benne a disszociatív értékelés, akkor is, ha egy másik jelentésréteg dicsér. Amikor Petőfi azt írja „enyelegve” Aranynak, hogy „Toldit most olvasom hatodszor. Csakugyan nyomorú fércmü. Még vagy hatszor elolvasom az idén, hogy silányságát minél jobban felfogjam" (RL. 333), világos, hogy el van ragadtatva a Tolditól, ami pozitív értékelés. Egyúttal azonban elhatárolódik azoktól az értékelésektől, amelyek silány fércmünek állítják be, és ettől lesz ironikus az idézet.

Az ironikus attitüdöt nehéz egyetlen átfogó kifejezéssel megragadni. A ,negatív”, „,kritikus”, „disszociatív” stb. jelzőkkel különböző szerzők erre tesznek kísérletet. Mint korábban leírtam, ,az irónia erőssége viszonylag széles skálán mozoghat, melynek pozitív végpontján - szerintem - az ugratás, negatív végpontján 
pedig a szarkazmus helyezhető el" (NEMESI 2009: 68). ${ }^{4}$ Nincs egyetértés abban, hogy az ugratás és az irónia, de még inkább az irónia és a szarkazmus ugyanaz a jelenség, különböző, egymásba folynak, vagy metszik egymást. Nézetem szerint egyik irányban sincs éles határvonal, szürke zónákról beszélhetünk inkább. Az olyan hétköznapi kifejezéseket is el lehet helyezni ezen az ugratás-irónia-szarkazmus attitüdskálán, mint a cukkolás, csipkelödés, élcelődés, évődés, fricskázás, heccelés, szurkálódás, zrikálás. Az iróniával járó egyik kockázat a szándékolt attitüd artikulálása, illetőleg azonosítása a félreértés veszélye miatt. A másik kockázat az arculatfenyegetésből (udvariatlanság) fakad (vö. BARBE 1995). Az explicit és a sugallt attitüdök sokféleképpen árnyalhatják, ,átszínezhetik” egymást (DEWSWINNER 1995; GARMENDIA 2018: 104-105); ezért érezzük úgy, hogy a LEECH $(1983,2004)$ által látszatudvariatlanságnak nevezett ugratás nem föltétlenül olyan barátságos és pozitív, mint az őszinte dicséret. Függetlenül az explicit jelentéstöl, amennyiben lappang implicit kritika az ugratás mélyén, akkor az ironikus is. Ha egyáltalán nem érzékelhető vagy teljesen explicit a negatív attitüd, akkor viszont nem beszélhetünk iróniáról.

5. Az ironikus alakzattársulások és a humoros irónia magyarázata. Ismert tény, hogy az irónia könnyen alkot alakzattársulásokat a túlzással, a litotésszel (tágabban: alullicitálással), a metaforával, a metonímiával és a költői kérdéssel (l. pl. KREUZ et al. 1996; TÁTRAI 2008: 314-315; NEMESI 2009: 126-129; KOMLÓSI 2013; DYNEL 2016). Ennek egyszerü az oka: semmi sem zárja ki, hogy az említett trópusokhoz/alakzatokhoz negatív implicit attitüd kapcsolódjon. Kizárná azonban az ilyen komplex alakzatokat a sokat bírált, de a válaszadó egyetemisták fele által megerősített quintilianusi definíció (az ellenkezője értendő azon, amit mondunk), hiszen például a túlzás nem az ellentétét sugallja valaminek, hanem nagyít vagy extrém módon kicsinyít, a litotész kevesebbet mond, mint ami az adott kontextusban adekvát lenne, és így tovább. Mivel ezek a trópusok/alakzatok maguk is grice-i maximasértéssel keletkeznek (bár vannak ebből a szempontból vitatott példák; 1. pl. NEMESI 2009: 95), nem pusztán együtt járhatnak az iróniával, hanem az irónia nyomravezetői is lehetnek. Az (5)-ben a metafora (,hazatalálni”, azaz visszatalálni a megfelelő hangnemhez) hozzásegít bennünket ahhoz, hogy megértsük Händel iróniáját:

(5) Egyszer Matthew Dubourg az egyik Händel-dal hegedűszólójának szabadon előadható részében hangnemröl hangnemre vándorolt, egyre hosszabban, mert úgy tünt, elfelejtette, melyikbe kell visszatérnie. Végül csak befejezte szólamát, de ha valakinek még kétsége volt, hogy mi történt, azt nyomban eloszlatta a jelen lévő szerző hangos bekiabálása: - Örülök, hogy hazatalált, Mr. Dubourg. (KzAk. 40-41; Ma. 93-94.)

A (6)-ban két alullicitálás-példát látunk. Az első lehetne eufemisztikus is, de inkább ironikusnak érezzük, mert olyasvalakiről van szó, aki annyira részeg volt,

${ }^{4}$ L. ugrat: „Hiszékenységénél fogva nevetségessé próbál tenni vkit” (ÉKsz. $\left.{ }^{1}\right)$, „Mulatságból, tréfaképp megtéveszt, heccel vkit” (ÉKsz. ${ }^{2}$ ); szarkazmus: „Keserü, maró gúny” (ÉKsz. ${ }^{1}$, ÉKsz. ${ }^{2}$ ). 
hogy összetörte a berendezést (GRICE 1975: 53, 1989/2011: 38). A második ellenben nem ironikus, mert a futballkommentátor implicit módon dicséri a Sevilla futballcsapatának játékosát, Kanoutét, nem pedig kritizálja (NEMESI 2009: 125):

(6) a) Egy kicsit becsipett.

b) És jön Kanouté is a Sevillába. Hát vele se fog gyengülni a csapat, ez azért sejthetö.

Nagyobb talány, gondolhatnánk, miképp hathat rendszeresen és határozottan humorosnak a sugallt negatív attitüd (1. a hallgatói válaszokat). Valójában nem nehéz a megfejtés. A humor inkongruenciafelfogása szerint a normasértés, szokatlanság, váratlanság, abszurditás, majd annak hirtelen feloldása mulattat; a fölényelméletek azt hangsúlyozzák, hogy az emberek hajlamosak mások hibáin, ügyetlenségén, felsülésén nevetni; a megkönnyebbüléselméletek pedig úgy tekintenek a humorra, mint egy szelepre, amelyen keresztül a feszültség kiereszthető (l. pl. SÉRA 1980; MARTIN 2007; MORREALl 2016). Az irónia implicit udvariatlansága, arculatfenyegetése olyan tolerálható normasértés, amely bizonyos nézőpontból, valaki(k)nek a nézőpontjából (1. 2.8.) kiszolgáltatottá teszi a célpontot a burkolt „csomagolású” védekező támadással szemben, valamilyen hibájára, tévedésére, tökéletlenségére irányítva rá a figyelmet (vö. GARMENDIA 2014). A 2. ábrában harmadik helyen szerepel 43\%-kal a feszültségoldás, konfliktuskerülés - vélhetően azért, mert az ironikus kritika, arculatfenyegetés indirekt (1. LEECH okfejtését a 2.5.-ből). Mi sem termékenyebb tehát a humor számára, mint éppen az irónia.

6. Összegzés. Levonhatnánk azt az ironikus következtetést a pragmatikaelméleti munkákat szemlézve, hogy miközben egyre többet tudunk a verbális irónia különböző megjelenési formáiról és müködésmódjáról, egyre bizonytalanabbak vagyunk a meghatározását illetően. A bizonytalanságot, úgy vélem, az okozza, hogy sokféle hasonlóságot lehet észrevenni az ironikus megnyilatkozások és kontextusaik, valamint az iróniával érintkező jelenségek között, amelyek vagy túláltalánosításra csábítanak, vagy ellenkezőleg: túlzott óvatosságra intenek. Utóbbi helyett, de remélhetőleg az előbbi veszélyt is elkerülve, amellett foglaltam állást, hogy az irónia lényegi jegye a sugallt negatív (kritikus, gúnyos, disszociatív, megkérdőjelező) attitűd, amely ütközik egy másik (nem negatív, nem kritikus), explicit vagy kevésbé implicit - ha úgy tetszik, fölismerhetően ,tettetett” - attitüddel. Ezt a felfogást támogatja számos kutató hasonló megállapítása és az a felmérés is, amelyben 100 magyar egyetemi hallgatót kérdeztem meg az irónia fogalmáról és funkcióiról. Érdekes lenne más korosztály(oka)t is megkérdezni, hogy kiküszöböljük (vagy legalább csökkentsük) a tankönyvi definíciók esetleges befolyását. Mindenesetre az irónia fönti minimalista értelmezése kézenfekvő magyarázatot ad az ironikus alakzattársulások gyakoriságára, ahogy az irónia humorára is. Az ÉKsz. ${ }^{1}$ és az ÉKsz. ${ }^{2}$ bevezetésben idézett tömör meghatározása tehát - a lexikográfus céljait és az olvasóközönség igényeit szem elött tartva - helytállónak mondható, még ha a pontosítás igényével mindegyik szavához külön-külön lenne is bőven hozzáfüznivalónk. 
Kulcsszók: irónia, ugratás, szarkazmus, humor, implikatúra, attitüd.

\section{Felhasznált források}

KzAk. $=$ Lebrecht, Norman 1985/2002. A komolyzene anekdotakincse. Vál. és ford. Szilágyi Mihály. Európa Könyvkiadó, Budapest.

Ma. = Muzsikus-anekdoták. Vál. Márkus János. Rózsavölgyi és Társa, Budapest.

\section{Hivatkozott irodalom}

Amante, DaVID J. 1981. The theory of ironic speech acts. Poetics Today 2: 77-96. https:// doi.org/10.2307/1772191

ATtARDO, SALVATORE 2000. Irony as relevant inappropriateness. Journal of Pragmatics 32: 793-826. https://doi.org/10.1016/s0378-2166(99)00070-3

AtTARDo, SAlVATORE - Eisterhold, Jodi - Hay, JenNifer - Poggi, IsABella 2003. Multimodal markers of irony and sarcasm. Humor 16: 243-260. https://doi. org/10.1515/humr.2003.012

Austin, JoHn L. 1962/1990. Tetten ért szavak. Akadémiai Kiadó, Budapest.

BARBE, KATHARINA 1995. Irony in Context. John Benjamins, Amsterdam-Philadelphia.

BROWN, ROBERT L. 1980. The pragmatics of verbal irony. In: SHUY, ROGER W. - SHNUKAL, ANNA eds., Language Use and the Uses of Language. Georgetown University Press, Washington. 111-127.

Castells, Manuel 1996/2005. A hálózati társadalom kialakulása. Gondolat-Infonia, Budapest.

Cicero, Marcus Tullius /2012. Cicero összes retorikaelméleti müvei. Szerk. AdAmiK TAMÁS. Kalligram, Pozsony.

Clark, Herbert H. 1996. Using Language. Cambridge University Press, Cambridge.

Clark, Herbert H. - Carlson, Thomas B. 1981. Context for comprehension. In: LONG, JoHN - BADDELEY, AlAN eds., Attention and Performance 9. Lawrence Erlbaum, Hillsdale (NJ.). 313-330.

Clark, HERBERT H. - GERRIG, RichARD J. 1984. On the pretense theory of irony. Journal of Experimental Psychology: General 113: 121-126. https://doi.org/10.1037//00963445.113.1.121

DEWS, SHELLY - WINNER, ELLEN 1995. Muting the meaning: A social function of irony. Metaphor and Symbolic Activity 10: 3-19. https://doi.org/10.1207/s15327868ms1001_2

DYNEL, MARTA 2013. Irony from a neo-Gricean perspective: On untruthfulness and evaluative implicature. Intercultural Pragmatics 10: 403-431. https://doi.org/10.1515/ ip-2013-0018

DYNEL, MARTA 2016. Two layers of overt untruthfulness: When irony meets metaphor, hyperbole or meiosis. Pragmatics \& Cognition 23: 259-283. https://doi.org/10.1075/ pc.23.2.03dyn

DYNEL, MARTA 2017. The irony of irony: Irony based on truthfulness. Corpus Pragmatics 1:3-36. https://doi.org/10.1007/s41701-016-0003-6 
DYNEL, MARTA 2018. Deconstructing the myth of positively evaluative irony. In: JOBERT, MANUEL - Sorlin, SANDrine eds., The Pragmatics of Irony and Banter. John Benjamins, Amsterdam-Philadelphia. 41-57. https://doi.org/10.1075/lal.30.03dyn

ÉKsz. ${ }^{1}=$ Magyar értelmező kéziszótár. Szerk. JuHÁSZ JÓZSEF - SzÖKE ISTVÁN - O. NAGY GÁBOR - KovAlovszKY MikLós. Akadémiai Kiadó, Budapest, 1972.

ÉKsz. ${ }^{2}=$ Magyar értelmező kéziszótár. Főszerk. PUSZTAI FERENC. 2., átdolgozott kiadás. Akadémiai Kiadó, Budapest, 2003.

FontANIER, Pierre /1968. Les Figures du Discours. Flammarion, Paris.

GARMENDIA, JoAnA 2010. Irony is critical. Pragmatics \& Cognition 18: 397-421.

GARMENDIA, JOANA 2014. The Clash: Humor and critical attitude in verbal irony. Humor 27: 641-659. https://doi.org/10.1515/humor-2014-0094

GARMENDIA, JOANA 2015. A (neo)Gricean account of irony: An answer to Relevance Theory. International Review of Pragmatics 7: 40-79. https://doi.org/10.1163/1877310900701003

GARMENDIA, JoAnA 2018. Irony. Cambridge University Press, Cambridge.

GIORA, RACHEL 1995. On irony and negation. Discourse Processes 19: 239-264.

GIORA, RaCHEL 2003. On Our Mind: Salience, Context, and Figurative Language. Oxford University Press, Oxford.

Grice, H. Paul 1975. Logic and conversation. In: Cole, Peter - Morgan, Jerry L. eds., Syntax and Semantics 3. Speech Acts. Academic Press, New York. 41-58.

Grice, H. PAUl 1978. Further notes on logic and conversation. In: CoLE, PETER ed., Syntax and Semantics 9. Pragmatics. Academic Press, New York. 113-127.

Grice, HerBert PAUL 1989/2011. Tanulmányok a szavak életéröl. Gondolat Kiadó, Budapest.

HÁMORI ÁGNES 2017. Diskurzusmüfaj, séma és forgatókönyv: a „vicc” müfaj sémájának jellemzői és kiépülési dinamikája a társas interakciókban. Magyar Nyelv 113: 311329. https://doi.org/10.18349/magyarnyelv.2017.3.311

HAVERKATE, HENK 1990. A speech act analysis of irony. Journal of Pragmatics 14: 77-109. https://doi.org/10.1016/0378-2166(90)90065-1

HoldCROFT, DAVID 1983. Irony as a trope, and irony as discourse. Poetics Today 4: 493511. https://doi.org/10.2307/1772029

Jorgensen, Julia - Miller, George A. - Sperber, Dan 1984. Test of the mention theory of irony. Journal of Experimental Psychology: General 113: 112-120. https:// doi.org/10.1037//0096-3445.113.1.112

KAUFER, DAVID S. 1981. Understanding ironic communication. Journal of Pragmatics 5: 495-510. https://doi.org/10.1016/0378-2166(81)90015-1

Keenan, Thomas R. - Quigley, Kathleen 1999. Do young children use echoic information in their comprehension of sarcastic speech? A test of echoic mention theory. British Journal of Developmental Psychology 17: 83-96. https://doi. org/10.1348/026151099165168

KOMLÓSI BOGLÁRKA 2007-2008. Az iróniakutatás elméleti dilemmái. Nyelvtudomány 3-4: 95-128.

KOMLÓSI BOGLÁRKA 2012. Az irónia mint „,kategóriaváltás” és ,pperspektívaváltás” a szemantika és pragmatika határán. Magyar Nyelv 108: 410-425. 
KOMLÓSI BOGLÁRKA 2013. A polarizációs tendencia szerepe az irónia nyilvánvalóvá tételében. A hiperbola és litotész mint nyomok az ironikus interpretációhoz. Magyar Nyelv 109: 409-420. https://doi.org/10.14232/phd.2594

KOMLÓSI BOGLÁRKA 2014. Most ironizálsz? Az irónia és az irónia kulcsingerei különböző nyelvi szinteken. Magyar Nyelvőr 138: 226-244.

KOMLÓSI BOGLÁRKA 2015. Az ironikus hozzáállás: út a szemétkosártól Jane Austen felé. In: Bódog AleXA - CsAtÁR PÉTER - NéMeth T. ENIKÖ - Vecsey Zoltán szerk., Használat és hatás. Loisir Kiadó, Budapest. 157-185.

Kreuz, Roger J. - Glucksberg, SAM 1989. How to be sarcastic: The echoic reminder theory of verbal irony. Journal of Experimental Psychology: General 118: 374-386.

Kreuz, Roger J. - Roberts, Richard M. - Johnson, BRENDA K. - BERTUS, EUGENIE L. 1996. Figurative language occurrence and co-occurrence in contemporary literature. In: KreuZ, Roger J. - MACNeALY, MARY SUE eds., Empirical Approaches to Literature and Aesthetics. Ablex, Norwood (NJ.). 83-97. https://doi.org/10.1037//00963445.118.4.374

LEECH, GeOFFrey N. 1983. Principles of Pragmatics. Longman, London.

LeEch, Geoffrey N. 2014. The Pragmatics of Politeness. Oxford University Press, Oxford.

Martin, RoD A. 2007. The Psychology of Humor: An Integrative Approach. Elsevier, Amsterdam.

Morreall, John 2016. Philosophy of humor. In: ZalTA, EdWARD N. ed., The Stanford Encyclopedia of Philosophy. https://plato.stanford.edu/archives/win2016/entries/ humor (2018. 12. 18.)

Muecke, Douglas Colin 1978. Irony markers. Poetics 7: 363-375.

NEMESI ATTILA LÁSZLÓ 2006. Szó szerinti jelentés, konvencionális jelentés, vezérjelentés. Világosság 47/8-10: 31-43.

NEMESI ATTILA LÁSZLó 2009. Az alakzatok kérdése a pragmatikában. Loisir Kiadó, Budapest.

Quintilianus, MARCUS FABIUS /2008. Szónoklattan. Szerk. ADAMIK TAMÁs. Kalligram, Pozsony.

RL. = Retorikai lexikon. Főszerk. ADAMIK TAMÁs. Kalligram, Pozsony, 2010.

ROBERTS, RichARD M. - KREUZ, ROGER J. 1994. Why do people use figurative language? Psychological Science 5: 159-163. https://doi.org/10.1111/j.1467-9280.1994. tb00653.x

ROCKWELL, PATRICIA 2000. Lower, slower, louder: Vocal cues of sarcasm. Journal of Psycholinguistic Research 29: 483-495.

SEARLE, JoHn R. 1969/2009. Beszédaktusok. AKTI-Gondolat, Budapest.

SEARle, John R. 1979. Expression and Meaning: Studies in the Theory of Speech Acts. Cambridge University Press, Cambridge.

SÉRA LÁSZLÓ 1980. A nevetés és a humor pszichológiája. Akadémiai Kiadó, Budapest.

SPERBER, DAN - WILSON, DEIRDRE 1981. Irony and the use-mention distinction. In: COLE, Peter ed., Radical Pragmatics. Academic Press, New York. 295-318.

Sperber, DAN - Wilson, DeIRDRE 1986/1995. Relevance: Communication and Cognition. Blackwell, Oxford. 
TÁTRAI SzILÁRD 2008. Irónia. In: SzATHMÁRI IsTVÁN föszerk., Alakzatlexikon. A retorikai és stilisztikai alakzatok kézikönyve. Tinta Könyvkiadó, Budapest. 311-320.

TÁTRAI SZILÁRD 2011. Bevezetés a pragmatikába. Funkcionális kognitív megközelítés. Tinta Könyvkiadó, Budapest.

TÁtrai SzILÁrd 2017. Pragmatika. In: TOlCSVAI NAGY GÁBOR szerk., Nyelvtan. Osiris Kiadó, Budapest. 897-1058.

Wilson, Deirdre - Sperber, Dan 1992. On verbal irony. Lingua 87: 53-76. (Magyarul: A verbális iróniáról. Helikon 52: 351-372.) https://doi.org/10.1016/00243841(92)90025-e

Wilson, Deirdre - Sperber, Dan 2012. Explaining irony. In: Wilson, DeIRdre SPERBER, DAN, Meaning and Relevance. Cambridge University Press, Cambridge. 123-145.

\section{Seeking the sine qua non of irony in theoretical pragmatics}

In this article, first, several theoretical pragmatic accounts of (verbal) irony are outlined and compared from Grice $(1975,1978)$ to present-day researchers. A number of examples, taken from musical anecdotes and the pragmatics literature, are discussed, including the controversial types. Then, the results of an empirical study are presented to shed light on the lay concept of irony: 100 Hungarian university students were asked to provide a definition, two examples and reasons why people use irony in communication. Based on their responses and the literature overview, it is argued that irony invariably conveys an implicit negative (sceptical, critical, dissociative, mocking, facethreatening) attitude that clashes with and overrides another, explicitly or less implicitly expressed evaluation. The ironic attitude is characterised as a continuum ranging from banter to sarcasm, with no sharp boundaries from both sides. This minimalist view of irony offers a natural explanation of the existence of humorous irony and ironic combinations of figurative language.

Keywords: irony, banter, sarcasm, humour, implicature, attitude.

NEMESI ATTILA LÁSZLó Pázmány Péter Katolikus Egyetem 